\title{
Director's Working Group
}

National Cancer Institute

\section{Source}

National Cancer Institute. Director's Working Group. NCI Thesaurus. Code C18746.

Ad hoc "think tanks" appointed to address key scientific issues. Their members include leaders in laboratory, clinical, and population-based research drawn from the extramural and intramural research community, staff of the NIH and other government agencies, members of professional organizations, and interested consumers and patient advocates. Their recommendations provide a framework for Institute strategic planning and for the development of operational plans by $\mathrm{NCl}$ divisions. (National Cancer Institute1999 Budget Request) 